\title{
Forest Inventory - Growth and Yield in Canada: Past, Present and Future
}

\author{
by
}

\author{
T.G. Honer ${ }^{1}$ and F. Hegyi ${ }^{2}$
}

\section{Introduction}

This summary of forest inventory - growth and yield in Canada presents selected highlights from the Canadian forestry literature. Development began in the early 1900's and has proceeded slowly, influenced by wars and depression, often resulting in a lack of continuity in reporting.

Forest inventory has been at the forefront of technological development as is evidenced by the application of aerial photographs, satellite imagery, geographic information systems and modern statistical theory. Growth studies have generally been carried on in a research environment. Emphasis has been on the study of competition, stand structure and development, and computer stimulation using data from permanent sample plots.

These highlights are presented for the periods to 1929 , the depression and war years to 1945 , the postwar period to 1972 , the present and the future.

\section{Forest Inventory and Research: The Years to 1929}

In the early development of Canada's forest resource, forest lookers or timber cruisers were sent into the woods to determine whether there was sufficient commercial timber on a proposed concession to warrant exploitation. They entered the forest by canoe using rivers and streams for access and cruised on foot, estimating timber volumes and often climbing tall trees to obtain a better view of the surrounding country. There were many tales concerning the accuracy of their estimates, but the methodology was highly subjective and depended upon the cruiser's years of experience, a sound knowledge of estimating procedures and the volume of lumber that could be sawn out from logs of various sizes.

As the provinces and the federal government assumed their respective responsibilities for forest management, the practice of forest inventory became more objective. It was evident that before management commenced, a forest survey was of prime importance, for it provided a quantitative description of the resource by species and size classes, the presence or absence of natural regeneration and timber type maps showing accessibility and the distribution of the resource over the area under study. The methodology of the forest survey was described by R.D. Craig, F.E., Inspector

\footnotetext{
Senior Mensurationist. Forestry Canada, Victoria, B.C.

${ }^{2}$ Director, Forest Inventory Branch, Ministry of Forests, Victoria, B.C.
}

of Forest Reserves (1). " ...the method which I have followed in conducting the forest survey ... consists in measuring with calipers at 4 1/2 feet from the ground, all the trees in strips 2 rods wide. The distance between the strips varies with the nature of the stand; where dense, or variable a one-eighth mile or a one quarter mile, but where burned over or very homogeneous, one-half or one mile is sufficiently close. At the end of each one-quarter mile (or 1 acre) a description of the topography, soil, undergrowth, and general silvicultural conditions is written on the back of the tally sheet and a new one started. Tally sheets are also changed with each change of type. From these notes and a rough sketch map we are enabled to make a map sufficiently accurate for foresty purposes.

"The party usually consists of four men, one who goes ahead with a hand compass and drags the chain, one calliper man on each side of the chain who measures all trees over 3 inches diameter breast-high within 1 rod of the chain the fourth acts as rear chainman and tallyman. The calliper men call out the number of 12-foot logs which they estimate can be cut from each tree as they give in the diameter.

"In addition to the valuation survey a certain percentage of trees which appear to be average trees of each diameter class are cut down and sawn into 10-foot sections, and at each cut the rate of growth for each decade taken. In this way it is possible to determine when the tree ceased to grow at a profitable rate. We are also enabled by this means to tell how much may be harvested annually without reducing the capital stock.

"Sample plots of reproduction usually $1 / 40$ acre are taken here and there to determine how many young trees of each species are on the plot. The age and rate of growth of these are also taken."

Growth and yield field procedures were initially an integral part of the forest inventory process, but as unrestricted harvesting continued and catastrophic fires decimated the forest, special investigations were initiated to assess the regeneration of forest and the effects of cutting practices on forest growth. The problems were particularly acute in the Prairie provinces where immigrants were streaming in to settle on the land.

The Forestry Branch, Department of the Interior, formed in 1899, had supported the establishment of forest reserves 
in western Canada to provide prairie settlers and farmers with a continuous supply of wood for fuel and lumber. Special investigations were initiated to report upon the reproduction of forests so that the silvicultural methods to be adopted in regulating cutting would result in the satisfactory regeneration of the stand.

The first comprehensive investigation of forest conditions in Alberta was conducted in 1911 on the Rocky Mountain Forest Reserve by T.W. Dwight (2). A graduate of the Faculty of Forestry, University of Toronto class of 1910, Dwight was employed as a Forest Assistant by the Forestry Branch, Department of the Interior. His assignment was to report on the forest conditions in the Reserve and provide general recommendations on the silvicultural treatment of the various types of forests.

Investigations were made on the Crowsnest and Bow River forests. His report contains descriptions of the forests and general silvicultural conditions as well as the first published, growth and yield table in Canada (Figure 1) for Engelmann spruce (Picea engelmanni) and lodgepole pine (Pinus contorta). Ancillary tables were also prepared showing volume (feet board measure) Scribner log rule, diameter growth, height growth, and seedling height growth to breast height ( 4.5 feet).

Dwight's methodology was direct and appropriate for the times. Eight plots on two sites in different locations, comprising one and a half acres were established in fully stocked, normal mature stands. Trees 10 inches and over were felled and measured for diameter and height, growth and volume. Diameter growth was measured by decades, the age at the upper end of each log was determined and the lengths of the logs and top were measured. The volumes of the trees as actually scaled were determined using the Scribner log rule and the volume per acre of the present stand was determined.

The intermediate yields were determined by calculating the dimensions of average trees at various ages using the growth curves and volume tables developed from the felled trees, and multiplying by the number of trees per acre on the plots. Mortality was assumed to be negligible since the yield was figured in board measure. While his tables are based on few plots and certain assumptions concerning normality and the growth of normal stands, Dwight's pioneering work is a forestry milestone in that it represents a first reasoned approach to forest harvesting, regeneration, growth and yield at a time when information on the forest resource and its response to cutting and fire was non-existent. Dwight set the standard for subsequent growth and yield investigative work and his methodology enhanced the forest survey procedures put into practice on the federal forestry reserves.

Reconnaissance forest surveys were initiated in several provinces by Canada's Commission of Conservation and provided an overview of the resource, its extent in timber volume and land area. But the very nature of the surveys necessitated only a cursory mention of forest growth and productivity.

The first research plot established to study forest growth was set out in 1917 at the Petawawa Forest Experiment Station, Chalk River, Ontario. Research had commenced on the growth, thinning and regeneration of white pine (Pinus strobus) and similar studies were initiated by the British Columbia Forest Service in 1921 to study the growth of coastal Douglas-fir (Pseudotsuga menziesii). The objective

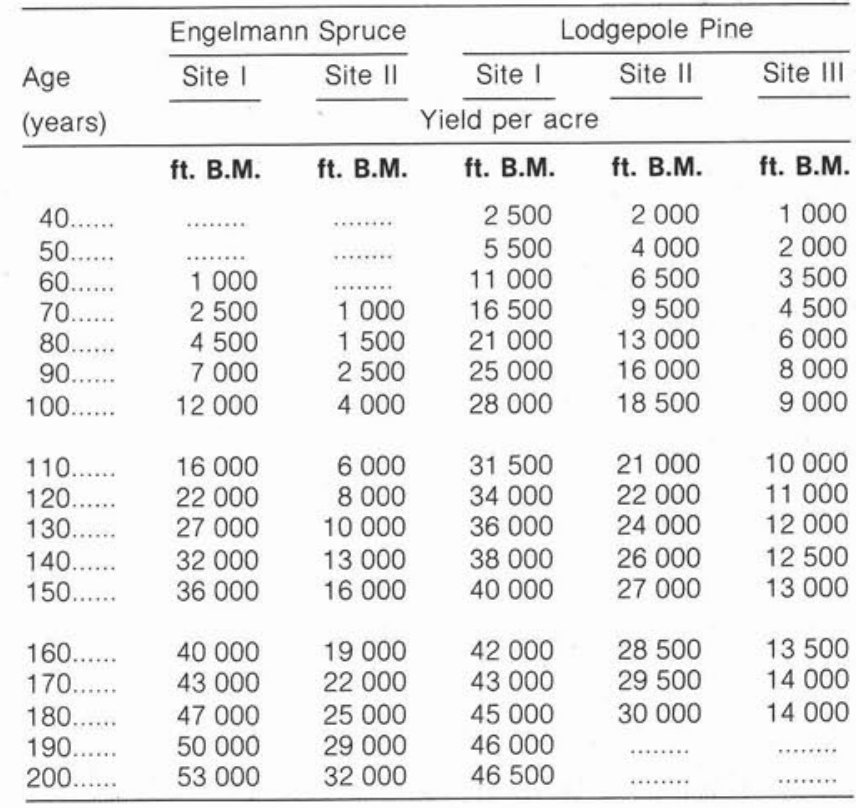

DENSITY AND AVERAGE SIZE MATURITY

\begin{tabular}{lrccccc}
\hline Species & Site & $\begin{array}{c}\text { Age } \\
\text { (years) }\end{array}$ & $\begin{array}{c}\text { Trees per } \\
\text { Acre } \\
\text { (number) }\end{array}$ & $\begin{array}{c}\text { Aver. diam } \\
\text { breast-high } \\
\text { (inches) }\end{array}$ & $\begin{array}{c}\text { Average } \\
\text { height } \\
\text { (feet) }\end{array}$ & $\begin{array}{c}\text { Average } \\
\text { volume } \\
\text { (ft. B.M.) }\end{array}$ \\
\hline Spruce & I & 200 & 182 & 16.5 & 92 & 281 \\
& II & 200 & 216 & 14.1 & 78 & 148 \\
Pine & & & & & & \\
& I & 200 & 204 & 15.1 & 87 & 237 \\
& II & 180 & 238 & 13.4 & 76 & 146 \\
& III & 180 & 292 & 9.3 & 55 & 48 \\
\hline
\end{tabular}

Figure 1. Normal yield-table for Engelmann spruce and lodgepole pine.

was to prepare yield tables based on growth figures obtained from permanent sample plots. These early efforts were initiated during a period of increasing concern as the forest resource gradually changed from large-sized old trees to younger trees of smaller dimension; from a resource of sawlogs and lumber to a forest of trees suitable for the production of wood pulp.

\section{The Depression and War Years 1929-1945}

On June 25-27, 1929 provincial and federal ministers and officials responsible for forest administration met in Ottawa to discuss the possibility of conducting a National Inventory of Forest Resources. The provinces insisted that they would be responsible for any inventories carried out within their jurisdictions, and lobbied hard for federal monies to support the proposal. The conference delegates were in agreement that common standards for inventory were desirable but because federal government funding was not forthcoming, the proposa remained dormant for the next two decades. However, before the conference ended, a resolution was passed urging federal-provincial cooperation in the acquisition of "reliable information... on the growing stock and increment accruing under existing conditions..." (3). During the next several years the federal Forestry Branch conducted investigations and worked co-operatively with provincial and industrial agencies to implement rate-of-growth surveys throughout the nation. Sampling was by 6.25 square mile blocks ( $1619 \mathrm{ha}$ ) chosen as representative of the forest types and growing conditions in the important forest regions of Canada. Each block 
contained 100 systematically spaced temporary sample plots $1 / 10$ acre $\left(405 \mathrm{~m}^{2}\right)$ in size. Estimates of gross current volume were derived from increment cores and diameter growth by diameter classes was computed. The estimated mortality of the past ten years was tallied and the net current growth was determined by deducting the mortality from the gross increment. As Bickerstaff et al. (4) have noted "the yields and mean annual increments tended to be high for young stands because of the older residual trees included, and low for older stands since some had been severely disturbed". The emphasis was on current growth after partial cutting and the results have been summarized by Candy (5) and in a series of reports by the Dominion Forest Service (see Bickerstaff et al. (4)). The mean annual increment of stands undisturbed by cutting seemed to be of little interest, probably because the provinces at that time, had no over-all provincial inventory to which the mean annual increment figures would apply.

Several projects based on permanent sample plots established in the 1920's have been well maintained and documented and are case studies on growth, yield and stand development. The reports of Ray (6) and Pfalzgraf (7) on the Lake Edward Experimental Area of Quebec, and of Jarvis (8) on the Goulais River Area in Ontario are examples that document 50 years of forest growth.

One of the most significant developments in forest inventory was the technique of forest air survey. Early in the 1920's studies on the use of aerial photographs had begun but it was during the Manitoba Pulpwood Survey of 1926-1927 that procedures were used operationally to assess the timber volumes on an area of 22000 square miles (5.72 million ha), in the northern part of the province.

An active participant in the field operation was H.E. Seely, a graduate of the Faculty of Foresty, University of New Brunswick. It was during this survey that Seely, the chief of party on the hundred-man cruise, conducted his first trials of the "selected line" method of sampling.

Some 25 years later Seely (9) published "A Forestry Survey Method" that described his selected line technique which depended on the photo interpreters ability to distinguish differences in stand height, forest type and canopy density; differences being more easily ascertained stereoscopically than absolute values. In selected line sampling, a line is drawn on the map without reference to detail visible on the photograph or on the ground and sample plots are located on this selected line with a similar avoidance of personal bias. The provisional stratification is revised from the ground samples. Results of selected line sampling with air photo stratification compare very well with those of systematic continuous strip sampling due to the stratification of forest types, better sample plot distribution and the use of statistical control.

But in the early 1930's Seely's interest in photogrammetry and measurement took precedence. By 1932 he had developed the shadow and oblique methods for determining tree heights from aerial photographs and had assessed the special value of winter photography for forestry purposes. Seely also developed and patented the "Seelyscope", a transfer device that provided a simultaneous view of map and photo together with a unique capacity for scale adjustment.

The depression years 1929-1939 severely reduced forestry research and operational activities in Canada, but one piece of work stands out as a major achievement of the era.
W.E.D. (Bill) Halliday, a graduate forester from the University of Toronto and employed by the Dominion Forest Service in Manitoba, began investigating the relationships existing between species occurrence and geographic regions based on climate and physiography (10). Funding for these studies was extremely limited and Halliday covered his own expenses on many of the field excursions. His original work - A Forest Classification for Canada - developed from an exhaustive review of historical records, survey reports and field examinations, was published in 1937 and set a high standard for the research that followed. In its revised form, it is the accepted standard reference (11) for the subdivision of Canadian forests into geographic regions and provides the necessary foundation for the development and reporting of Canadawide forest productivity estimates.

In western Canada, however, one province, British Columbia was conducting a forest inventory and compiling the results with a new technique. "IBM punch cards" were being used and the application of systems and machine processes would ultimately revolutionize forecasting procedures and the development of growth and yield models. But by 1939 the country was at war and forestry research and development activities remained dormant until hostilities ceased in 1945.

\section{Post War 1946-1972}

In the post war period, forest inventory - growth and yield activities expanded rapidly. The Canada Forestry Act of 1949 provided the means for the federal government to reactivate the 1929 concept of a national forest inventory and cooperate with the provinces in cost-shared agreements for forest inventory and reforestation. The federal government undertook to pay one-half the cost of completing and maintaining forest inventories during the next five years for reconnaissance surveys and provincial surveys designed for national and provincial inventory statements (12). Under these agreements a gross area of 275 million ha was surveyed.

The standards employed were set forth in Schedule A of the Agreements. surveys

"Part 3: General specifications for forest inventory

1. If the proportion of the total area of a province occupied by forests is small, reconnaissance surveys based on photography on a scale of 1:40,000 should be undertaken. Forest areas to be outlined on planimetric maps on a scale of $1: 63,360$. Forested areas to be rephotographed at $1: 15,840$.

2. If proportion of forest areas is large, original photography to be at 1:15,840, and mapping at a scale not smaller than $1: 63,360$ or larger than $1: 15,840$.

3. Federal assistance may be extended to share the cost of phot-lithographed forest maps at a scale not larger than $1: 63,360$, provided such maps follow an approved system of forest classification. legend, etc.

4. Ground sampling to be based upon distribution of different forest classes as determined from aerial photos.

5. Stratified random sampling procedures should be followed where conditions of accessibility permit. Wherever random sampling cannot be used because of excessive cost and 
technical difficulties, some pattern of selective sampling should be adopted. Sampling procedures should be designed to give gross volume estimates of a probably error of plus or minus 10 per cent. In the smaller provinces independent estimates may be made for areas of about 500,000 acres $(202,343 \mathrm{ha})$ of forest land; in the larger provinces for unit areas of about $1,000,000$ acres." $(404,686$ ha $)$

The provincial inventory designs differed from region to region depending upon the intensity of the information required, value and accessibility of timber, land tenure and cutting rights. Aerial photographs were taken, forest maps produced, and sample plots established in well distributed locations in forest classes determined from the aerial photographs.

Growth studies were initiated as an integral part of provincial surveys or as complementary studies. Normal yield tables were prepared in Nova Scotia (13) and Ontario (14) and empirical yield tables in British Columbia (15). In Saskatchewan a set of permanent plots were established independent of the inventory and provided yield tables for spruce (16), jack pine (17), and aspen (18).

As a result of the Canada Forestry Act of 1949, national estimates of Canada's forest resource became available and were updated on a five-year basis. The provincial forest services, working cooperatively with the federal government through the Canadian Forest Inventory Committee, contributed to the Candian Forest Resource Data System, established to receive, store and report data at the provincial and national level. Canada's Forest Inventory 1981 (19) was the most comprehensive summary published and was followed by the updated version in 1989 (20).

Research studies expanded to investigate the relationship between forest growth and the growing site. HIIIs (21) in Ontario took a holistic approach to total site classification using physiographic, biological and cultural factors with emphasis on the physiographic factors which are estimated on numeric scales. HIII's general methodology was used by MacLean and Bedell (22) in their growth and yield survey of Ontario's northern clay belt and it proved to be very satisfactory. The sites were easily recognized on the ground and from air photos and provided a good separation of the height/age curves. Additional studies in progress at the time were those conducted in the Maritimes by Louks (23) which emphasized detailed mapping at 1:1267 200 and a three-level classsification system where Forest Zones < Ecoregions < Site Districts. In British Columbia, the work of Krajina (24) in describing the biogeoclimatic zones of the province was particularly important and would later influence all aspects of silviculture, stand management and forest growth in the province.

By the early 1960's machine processing of forestry data was common practice and scientific computers were being introduced into the universities and major research establishments. A natural development was the establishment of models to mimic the growth of forest trees and stands. Newnham's (25) work is particularly significant for in developing a stand model for Douglas fir, he opened new avenues of investigation which would permit other scientists $(26,27,28)$ to expand the modelling process to various species and forest zones and investigate the effects of competition and stand treatments on future volume yields.

\section{The Present 1972-1989}

In a country the size of Canada forest inventory has always been an expensive undertaking and foresters were always seeking ways to reduce costs and improve the accuracy of their estimates. Aerial photography provided the means to accurately classify and map the forest and sampling techniques and statistical theory provided the estimates and confidence levels. However, the advent of large scale photography (LSP) resulted in a major innovation in survey methodology; multi-stage sampling now became a reality.

Much of the initial research work was initiated by SaynWittgenstein and his associates (29), and Lyons (30) in British Columbia. Surveys were carried out in a number of provinces but it was in British Columbia that multi-phase sampling, combined with GIS and satellite image analysis, received its greatest support. This inventory process was initiated in 1980, composed of LSP, selected ground samples and designated growth and yield plots. It is an integrated design that links growth and yield estimates to the inventory strata, as well as accomodating periodic updates (31).

A comprehensive assessment of growth and yield investigations in Canada is presented by Bickerstaff and his associates (4). The mean annual increment by land classes within Forest Regions and Sections is also shown (32). This two-volume work contains summaries of all published reports and presents the first national estimate of the productive capacity and growth of Canada's forest by ecological and political subdivisions. It provides a bench-mark level of productivity against which increases from intensive silvicultural practices can be estimated.

\section{Evolution of High-Tech Era}

Prior to the 1940's, traditional forest inventory practices consisted mainly of ground surveys. During the late 40's and early 50's the use of aerial photographs was introduced for the purposes of subdividing the forest into relatively homogenous strata as well as for controlling ground sampling $(33,34)$. Applications of statistically efficient sampling designs to forest inventory were also receiving increased attention (34-39).

Forest inventory techniques are well documented in books (40-42) and in the proceedings of the various symposia (43-47). In addition, publications focusing on statistical efficiency $(48,49)$, growth and yield projections $(50)$, remote sensing techniques (51) and geographic information systems (52-54), also contain relevant information for forest inventory. These developments made increasing use of computers and advanced technology. At the same time, emphasis was placed on the need for current information that can be manipulated in a flexible way (56). The basic ingredients of such a land information system are: geo-referenced planimetric, cadastral and thematic maps within the context of a geographic information system, cost effective change detection procedures, and flexible data management algorithms (57-63). Canadian forest inventory practices were in the forefront of these new developments.

In recent years, considerable attention has been focused on global monitoring (64-69). Geographic information systems have perhaps made the greatest impact on forest inventory practices and their operational implementation has received considerable attention $(70,71)$. 


\section{Future Trends}

Given the available modern technology, the following steps summarize inventory practices that will be used operationally in Canada in the near future.

\section{Preparation of Base Maps}

1. Starting with planimetric maps, ownership, cadastre and administrative boundaries can be entered to form the base map. Automation of this process with GIS is costeffective and provides the opportunity of storing the various sources of information as levels, facilitating further manipulations with thematic and topographic information.

2. Acquisition of vertical aerial photographs at $1: 15,000$ or $1: 10,000$ scales. These photographs need to be interpreted to provide descriptions of forest cover. For example, individual species composition may be determined to the nearest $10 \%$, otherwise species groups or other relevant ecological units may have to form the description of the forest cover. Date of stand establishment or age, if available, and total height (e.g., average height of 100 largest stems per hectare) of the leading species is estimated next. In order to improve the estimation of volumes of individual stands, some measure of stocking is important, such as crown closure to the nearest $10 \%$ or stems per hectare. In addition, other relevant information may be included in the attribute list, such as site index or site type, estimated volume, stand history, etc.

\section{Interpretation of Aerial Photographs}

3. Using ground control information and field samples, the interpretation of aerial photographs is confirmed. Photo centres and the boundaries of homogeneous types are transferred onto base maps either photogrametrically or directly into the GIS. High quality forest cover maps can then be prepared with the aid of the computer.

\section{Sampling}

4. A sampling system that may be most cost-effective and efficient would likely involve both large scale photo and ground samples. Experience indicates that $70 \mathrm{~mm}$ stereo photos at 1:500 scales are highly suitable for the estimation of photo volumes. Random distribution of photo samples is preferred, with the aim of representing adequately the major population groups. A sub-sample of the areas selected for photo samples can then be chosen randomly and visited on the ground for detailed measurements. Ground and photo samples can then be analyzed according to procedures outlined under multi-phase sampling (40).

\section{Statistical Analysis and Volume Estimation}

5. In addition to the formal statistical analysis, volume equations may be derived from the sample data base, using independent variables which are compatible with the classification system. This approach allows volume estimation on an individual stand basis, a capability that is becoming increasingly important in multiple and integrated resource management, mainly because it facilitates the examination of different land use options.

\section{Resource Overlays}

6. The major advantages of using a GIS for processing the inventory data are that the thematic forest cover and multi-resource levels can be combined with cadastre, administrative boundaries, and other relevant levels of information that are available in digital or geo-referenced forms. Using either vector or raster based overlay procedures, areas of resultant polygons can be determined and the results displayed graphically, including colour enhanced thematic maps. As well, the statistical data may be manipulated in a flexible manner to provide a wide range of summaries.

\section{Growth and Yield}

7. An integral part of any forest inventory is growth projections. Again, literature contains several approaches, including deterministic volume equations with time as one of the independent variables, stochastic models, and simulation models. The use of expert systems in growth projections will probably pick up momentum and may replace conventional approaches to a large degree.

The above described procedures may be enhanced by the use of satelite image data. For example, supervised classification of thematic mapper imagery can provide useful information for the planning of forest inventory projects, including both the classification and sampling.

For resource monitoring and change detection, satellitedata provide perhaps the most cost-effective solution. For example, imagery obtained at two different times and subjected to multi-temporal analysis provides opportunities far beyond the capabilities of any of the conventional techniques. Changes detected can be transferred to existing forest cover maps, or entered directly into the GIS. A more sophisticated option is to use an integrated satellite image analysis and geographic information system to monitor and manage change data, an approach that will be fully operational in Canada during the next few years. Public pressure for having up-todate information in resource management suggests that change monitoring needs to be completed every two years.

\section{References}

1. Craig, R.D. 1907. Report of the inspector of forest reserves. Appendix No. 2. Supt. For. Dept. Interior Sessional Pap. No. 25. in Ann. Rep. Dept. Interior, Canada.

2. Dwight, T.W. 1913. Forest conditions in the rocky mountains forest reserve. For. Branch Bull. 33, Dept. Interior, Canada. 62 p.

3. Gillis R. Peter and Thomas R. Roach. 1986. Lost initiatives: Canada's Forest Industries, Forest Policy and Forest Conservation. Greenwood Press, New York. $326 p$

4. Bickerstaff, A. and S.A. Hostikka. 1977. Growth of forests in Canada. Part 1: An annotated bibliography. Forest Manage Inst Inf. Rep. FMR-X-98, Can. For. Serv. Fisheries and Environment Canada.

5. Candy, R.H. 1938. Review of reports on growth and regeneration surveys in Canada conducted by the Dominion Forest Service and the Commission of Conservation 1918-1936. Can. Dep. Mines Resour., For. Branch Bull. 90.50 p.

6. Ray, R.G. 1956. Site types, growth and yield at the Lake Edward Forest Experiment Area, Quebec. Can. Dept. North. Aff. Nat. Resourc., For. Res. Div., Tech. Note 27, 53 p.

7. Pfalzgraf, Jacques. 1975. La foret experimentale du Lac Edouard. Milieu 10:L 24-29.

8. Jarvis, J.M. 1960. Forty-five years growth on the Goulais River watershed. Can. Dept. North. Aff. Nat. Resour., For. Res. Div., Tech. Note 84, $31 \mathrm{p}$.

9. Seely, H. E. 1955. A forest survey method. Can. Dept. North. Aff. Nat. Resour., For. Res. Div., Techn. Note 8.

10. Halliday, W.E.D. 1937. A Forest Classification of Canada. Can. Dept. Mines Resour., For. Branch, Bull. 89. 50 p. + map.

11. Rowe, J.E. 1972. Forest Regions of Canada. Can. Dep. Environ., Can. For. Serv., Dept. Publ. 1300. 171 p + map.

12. Seely, H.E. 1957. Forest inventories in Canada. Can. Dept North. Aff. Nat. Resour., For. Branch Misc. Publ. 8, 11 p.

13. Hawboldt, L.S. and S.N. Kostjukovits. 1961. Forest regulation for Nova Scotia. Part 1: site quality and normal yield tables for softwoods. Nova Scotia Dep. Lands For. Bull. No. 27 p.

14. Plonski, W.L. 1960. Normal yield tables for black spruce, jack pine, aspen, white birch, tolerant hardwoods, white pine and red 
pine for Ontario. Ont. Dep. Lands For., Silvic. Ser. Bull. No. 2. $39 p$

15. Fligg, D.M. 1960. Empirical yield tables. B.C. For. Serv., Victoria, For. Surv. Notes No. 6. $13 p+$ tables.

16. Kabzems, A. 1971. The growth and yield of well stocked white spruce in the mixedwood section in Saskatchewan. Sask. Dep. Nat. Resour., Tech. Bull. No. 5. 75 p.

17. Kabzems, A. and C.L. Kirby. 1956. The growth and yield of jack pine in Saskatchewan. Sask. Dep. Nat. Resour., For. Branch, Tech. Bull. 2. 66 p

18. Kirby, C.L., W.S. Bailey and J.G. Gilmour. 1957. The growth and yield of aspen in Saskatchewan. Sask. Dep. Nat. Resour., For. Branch, Tech. Bull. 3, $67 p$

19. Bonnor, G.M. 1982. Canada's Forest Inventory 1981. Can. For. Serv., Environ. Can. 23 p + maps + tables.

20. Anon. 1988. Canada's Forest Inventory 1986. For. Can. 60 p.

21. Hills, G.A. 1952. The classification and evaluation of site for forestry. Ont. Dep. Lands For., Div. Res., Res. Rep. No. 2341 p.

22. MacLean, D.W. and G.H.D. Bedell. 1955. Northern clay belt growth and yield survey. Can. Dep. North. Aff. Nat. Resour., For. Res. Div., Tech. Note 20. 31 p.

23. Louks, O.L. 1962. A forest classification for the Maritime Provinces. Can. Dep. For., reprint from Proc. Nova Scotia Inst. Sci., Vol. 25, Part 2. $167 p$

24. Krajina, V.J. (ed) 1965. Ecology of Western North America. Vol. 1. Univ. B.C., Dep. Botany. 111 p. (Symp. proc.)

25. Newnham, R.M. 1964.The development of a stand model for Douglas fir. Univ. B.C., Fac. For., Ph.D. Thesis.

26. Arney, James D. 1972 Computer simulation of Douglas fir tree and stand growth. Can. Dep. Environ., Can. For. Serv., Pac. For. Res. Cent., Intern. Rep. BC-27, 79 p. Unpubl. Rep.

27. Bella, I.E. 1970. Simulation of growth, yield and management of aspen. Univ. B.C., Fac. For., Ph.D. Thesis. 190 p.

28. Mitchell, Kenneth J. 1969. Simulation of the growth of even-aged stands of white spruce. Yale Univ. School of For., Bull. 75. 48 p.

29. Sayn-Wittgenstein, L. and A.H. Aldred. 1969. A forest inventory by large-scale aerial photography. Pulp and Paper Mag. Can. 70 (17): 92-95.

30. Lyons, E.H. 1967. Forest sampling with $70 \mathrm{~mm}$ fixed air-base photography from helicopters. Photogrammetria 22: 213-231.

31. Hegyi, F. 1983. Mapping and satellite image analysis for forest inventory. In Proceedings: Renewable source inventories for monitoring changes and trends. Oregon State Univ. Corvallis.

32. Bickerstaff, A., W.L. Wallace and F. Everet. 1979. Growth of forests in Canada. Part II. Mean annual increment by forest regions and provinces. A quantitative description of the land base and the mean annual increment. Petawawa Nat. For. Inst. Info. Rpt. PI-X-1.

33. Spurr, S.H. 1948. Aerial Photographs in Forestry, The Ronald Press Co., New York.

34. Spurr, S.H. 1952. Forest Inventory, The Roland Press Co., McGrawHill Book Co., New York.

35. Bruce, D. and F.X. Schumacher 1942. Forest Mensuration, McGrawHill Book Co., New York.

36. Bickford, C.A. 1952. The sampling design used in the forest survey of the Northeast: J. For. 50: 290-293.

37. Cochran, W.G. 1953. Sampling Techniques, John Wiley \& Sons, New York.

38. Dawkins, H.C. 1952. Experiments in low percentage enumerations of tropical high forest with special reference to Uganda: Emp. For. Rev. 31: 131-145

39. Snedecor, G.W. and W.G. Cochran 1956. Statistical Methods, The lowa State College Press, Ames.

40. Loetsch, F. and K.E. Haller. 1973. Forest Inventory, Vol. I and II BLV Verlagsgesellschaft, Munchen

41. Husch, B., Miller C.I., and T.W. Beers. 1972. Forest Mensuration. The Ronald Press Co., New York.

42. Avery, T.E. 1975. Natural Resources Measurements. McGraw-Hill Book Co., New York.

43. Cunia, T. 1974. (ed.) Proceedings: Monitoring forest environment through successive sampling, IUFRO S4.02, Syracuse, New York.

44. Lund, H.G. 1978. (ed.) Proceedings: Integrated inventories of renewable natural resources, Univ. Arizona, Tuscon.

45. Frayer, W.E. 1979. (ed.) Proceedings: Forest resource inventories, Vol I and II, Colorado State Univ., Fort Collins.
46. Brann, T.B. House, L.O., and H.G. Lund (ed.) 1981. Proceedings In-place resource inventories: principles and practises, Univ. Maine, Orono.

47. Bell, J.F. and T. Atterbury (ed.) 1983. Proceedings: Renewable resource inventories for monitoring changes and trends, Oregon State Univ. Corvallis.

48. Ware, K.D. and T. Cunia, 1962. Continuous forest inventory with partial replacement of samples, For. Sci. Monog. 3.

49. Freese, F. 1962. Elementary Forest Sampling. Agric. Handbook No. 232

50. Fries, J. 1974. (ed.) Proceedings: Growth models for tree and stand simulation, IUFRO S4.01-4, Stockholm, Sweden.

51. Johansen, C.J. and J.L. Sanders, 1982. Remote sensing for forest management, Soil Conserv. Soc. Amer. Ankeny, lowa.

52. Weller, B.S. 1983. (ed.) Proceedings: Automated cartography: international perspectives on achievements and challenges, Vol I and II, Auto-Carto Six, Ottawa, Canada.

53. Anon. 1988. Report of a Workshop: GIS: Geographic information systems, ESCAP/UNDP, Bangkok, Thailand.

54. Anon. 1989. Proceedings: Challenges for the 1990's GIS, Ottawa, Canada

55. McPhalen, J. 1989. (ed.) Proceedings: GIS 89: A wider perspective, Vancouver, Canada

56. Hegyi, F. 1985. Opportunity for increasing the scope and efficiency of forest planning through high technology. In Proceedings: Twelfth Commonw. For. Conf., Victoria, Canada.

57. Hegyi, F. and R.V. Quenet, 1983. Integration of remote sensing and computer assisted mapping technology in forestry: Can. J. Remote Sensing 9: 92-98

58. Hegyi, F. 1988. Key factors in an operational GIS for land use planning. In Report of a Workshop on GIS: Geographic Information Systems, ESCAP/UNDP, Bangkok, Thailand

59. Kirkland, A. 1985. Data needs and recent developments in resource management and planning. In Proceedings: Twelfth Commonw. For. Conf. Victoria, Canada.

60. Beaudoin, M. 1988. The Landsat Thailand project resource information management system in Thailand: Overview and trends in GIS systems. In Report of a Workshop on GIS: Geographic Information Systems, ESCAP/UNDP, Bangkok, Thailand.

61. Tveitdal, S. and O. Hesjedal, 1989. GIS in the Nordic countries. Proceedings: GIS 89: A wider perspective, Vancouver, Canada.

62. Mok, S.T., Anis, Z., and A Ramlee. 1988. Promoting remote sensing and GIS applications in forestry in Asean. In Proceedings: Ninth Asian Conf. on Remote Sensing, Bangkok, Thailand.

63. Hoffer, R.M. and K.S. Lee. 1989. Forest change classification using Seasat and Sir-B satellite Sar data. In Proceedings: IGARS'89 Quantitative Remote Sensing: An Economic Tool for the Nineties, Vancouver, Canada

64. Hildebrandt, G. 1983. Needs for monitoring renewable resources and national ecosystems - a global prospective. In Proceedings: Renewable resource inventories for monitoring changes and trends, Oregon State Univ. Corvallis

65. Singh, K.D. and J.P. Lanly. 1983. A review of FAO's contributions to assessment and monitoring of tropical forest resources. In Proceedings: Renewable resource inventories for monitoring changes and trends, Oregon State Univ. Corvallis

66. Schmid-Haas, P. 1983. Swiss continuous forest inventory, twenty years experience. In Proceedings: Renewable resource inventories for monitoring changes and trends. Oregon State Univ. Corvallis.

67. Lund, H.G. 1983. Change: now you see it - now you don't. In Proceedings: Renewable resource inventories for monitoring changes and trends, Oregon State Univ. Corvallis.

68. Hagglund, B. 1983. The new national forest survey. In Proceedings: Renewable resource inventories for monitoring changes and trends. Oregon Stat Univ. Corvallis.

69. Hegyi, F. 1983. Mapping and satellite image analysis for forest inventory. In Proceedings: Renewable resource inventories for monitoring changes and trends. Oregon State Univ. Corvallis.

70. Tomlinson, R.F. 1989. Geographic information systems challenges for the 1990's. In Proceedings: Challenges for the 1990's GIS, Ottawa, Canada

71. Hegyi, F. 1989. The role of GIS in Provincial inventories. In Proceedings: GIS 89: A wider perspective, Vancouver, Canada. 


\section{H.E. Seely (1898-1982). Forest Inventory Innovator}

H.E. (Si) Seely, a graduate forester from the University of New Brunswick, began his career in 1917 engaged in a forest survey of New Brunswick. In 1919 he worked on a forest survey of the Petawawa area of Ontario and joined the Canadian Forestry Service in 1920 as a Forest Assistant in western Canada. He served as a crew chief in the 1927 survey of forest resources of Manitoba and following his transfer to Ottawa headquarters began his investigations into the use of aerial photographs for the identification of tree species, forest cover types, and the derivation of timber volume from tree height, crown and density measures. During World War II he served in military intelligence utilizing his skills in air photo interpretation. Si returned to the Forestry Branch as Chief, Forest Inventory Section, where he and his small team of foresters and technicians investigated experimental air photography and sampling methods for forest inventory.

Research on the use of aerial photographs initially focused on the determination of tree heights from oblique photos, from shadow measurements on snow and using the parallax and displacement methods. One of his major developments, which was applied in mapping the forests of the northern territories, was the forestry tri-camera method of photography. It used a central vertical photograph with starboard and port obliques so that a wide swath of country was covered in one flight. The oblique photographs gave a more informative view of the timber and were more economical than other methods in use of the time. Another aspect of the research was the use of large-scale photographs taken with the Vinton 70 millimetre camera. They gave much greater detail and individual photographs could be used as sampling units in conjunction with a forest cover stratification system.

An important contribution to forest survey methodology was the introduction of the "Selected Line Method" of forest sampling. As Si stated in a 1972 interview "....when we used air photographs, we no longer needed cut base lines. The lakes and streams, and all the topographical detail which were accurately plotted from aerial photographs, served as sufficient control for any of our forest cruises. We didn't need to cut these expensive base lines and we no longer ran systematic lines between base lines. We tied (our cruise lines) to the topographic detail. We had good base maps made from oblique photographs ... so that when it came to sampling methods ... we were no longer tied down to systematic surveys. Cruise lines were just run between recognizable points on the map. You joined up the recognizable points without regard to cardinal directions, and you put your plots along those lines. It was not a random selection, it was not systematic, and we argued that it had no personal bias. In tests that we made, we found that it gave results indistinguishable from random sampling ... without the expense of random sampling. The technique has been used in various Canadian provinces, in India, Africa and other countries.'

The procedures developed by Seely and his associates formed the basis for the implementation of statistically designed sampling systems currently in use throughout Canada.

\section{T.W. Dwight (1889-1977). Canada's Father of Forest Mensuration}

Born in Geneva, Illinois, T.W. (Ted) Dwight received his early education in Picton Ontario, A Bachelor of Science in Forestry from the University of Toronto and a Master of Forestry from Yale University. Upon graduation, he joined the Dominion Forest Service, served in western Canada and was
Assistant Director of Forestry until 1922. From 1923 until his retirement in 1957, Dwight was Professor of Forest Mensuration at the Faculty of Forestry, University of Toronto, where he indoctrinated would-be foresters, for better or for worse, in the magic and mystery of forest measurement and regulation.

Theodore Woolsey Dwight was a forestry pioneer and a member of the Faculty of Forestry's second graduating class. As he explained in a 1972 interview "to be considered a pioneer in forestry in Canada, you must be able to give ... evidence that you were employed on the Riding Mountain Forest Survey". This early forest inventory which covered more than a million acres in the province of Manitoba, was conducted in 1906-1908 and involved systematic sampling by half-chain strips at half-mile intervals. Dwight gained valuable field experience while on the survey and later, undertook an extensive investigation of the forest conditions in the Rocky Mountains of Alberta. His report, published in 1913 , was the first appraisal of Alberta's timber resource and the effects of lumbering on natural regeneration. It contains Canada's first growth and yield table.

Dwights penchant for logical thought and attention to detail were either boon or bane to his associates and students. He was totally absorbed in forest mensuration and personally knew and had met with every major forest mensurationist in Germany, Scandinavia and Europe. His knowledge of volume tables and yield tables, their strengths and weaknesses, was comprehensive. Lecturing, however, was not his forte but to the relief of his many students, he supplemented his talks with detailed notes and computational exercises. $\mathrm{He}$ always had time for his students and a real interest in their athletic abilities as well as their academic endeavors.

Ted Dwight took a great deal of satisfaction in working out technical details for various mathematical relationships concerning tree volume and growth funcitons. His algebraic formula to estimate individual tree volume was a six-term equation that involved three single variables and three interaction terms. While he recognized that trees could have different stem forms, he was not a proponent of form class volume tables. As he often stated, a successful method for determining the form quotient of standing trees and a method of determining the average form quotient for a forest stand had not been developed. He concluded that better results could be obtained by using tables that do not include form class, as the additional accuracy attributable to form class estimates was overshadowed by the error in measuring or estimating the formclass for standing trees

Dwight was particularly pleased with his development of the co-frequency method for determining the diameter growth of trees. The method uses the diameter of the hundred largest trees per acre and was apparently developed simultaneously by foresters, colleagues of Dwight, in Switzerland and in Germany. His contacts with these men and his continuing correspondence and investigation brought him much personal satisfaction as well as international recognition. The use of the hundred largest trees per acre ultimately lead to its adoption for defining top height and plot age for site index determination

Dwight's legacy continues at the University of Toronto through scholarship and athletic awards, and Canadian mensurationists who were fortunate to have studied under his tutelage will always have a warm feeling for him. He was a big man in stature and intellect, and a gentle friend to many. Truly, he is a father of forest mensuration in Canada. 
FORESTRY CANADA MANAGING THE IMPACT OF CLIMATE CHANGE

Forestry Canada is a leader in the international effort to understand, forecast and manage the impact of global climate change.

Forestry Canada, in cooperation with other departments, provincial governments, universities, international agencies and the forest industry, is participating in research on topics as diverse as the effect of atmospheric change on tree physiology and on policy implications for the forest products market. Our common objective is to anticipate and minimize the impact of any dramatic or negative climate changes on our shared forest systems.

As Canadians, we all recognize that benefits from our forests include not only wood products but water resources. wildlife habitat and recreational opportunities. Forestry Canada's policies and research programs are aimed at enhancing those benefits.

Ultimately, our goal is to ensure sustainable development of the forest ecosystem.

You can find out more by contacting:

Forestry Canada Science Directorate Ottawa, Ontario K1A 1G5

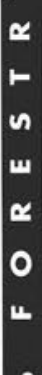

\section{FORÊTS CANADA}

ET LA GESTION DES

CHANGEMENTS CLIMATIQUES

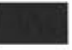

Forêts Canada est un leader dans l'effort international pour comprendre et prédire l'effet des changements climatiques sur le plan mondial et en gérer l'impact.

Le ministère participe, de concert avec d'autres ministères, les gouvernements provinciaux, les universités, les organismes internationaux et l'industrie forestière, à des recherches sur des sujets variés, tels que l'effet des changements atmosphériques sur la physiologie de l'arbre ou la portée des politiques qui se rapportent au marché des produits forestiers. Ensemble, nous nous efforçons d'anticiper et de minimiser l'impact des changements critiques dans le climat sur nos forêts.

En tant que Canadiens, nous constatons tous qu'en plus des produits du bois, la forêt nous fournit d'autres bénéfices, comme les ressources en eau, un refuge pour la faune et un lieu de divertissements. Tant par nos politiques que par nos programmes, notre ministère s'applique à améliorer ces bénéfices.

En fin de compte, Forêts Canada cherche à assurer le développement soutenu de l'écosystème de nos forêts.

Pour de plus amples informations, veuillez communiquer avec:

Forêts Canada Direction générale des sciences Ottawa (Ontario) K1A 1G5 Forestry Forêts
Canada Canada Canadä

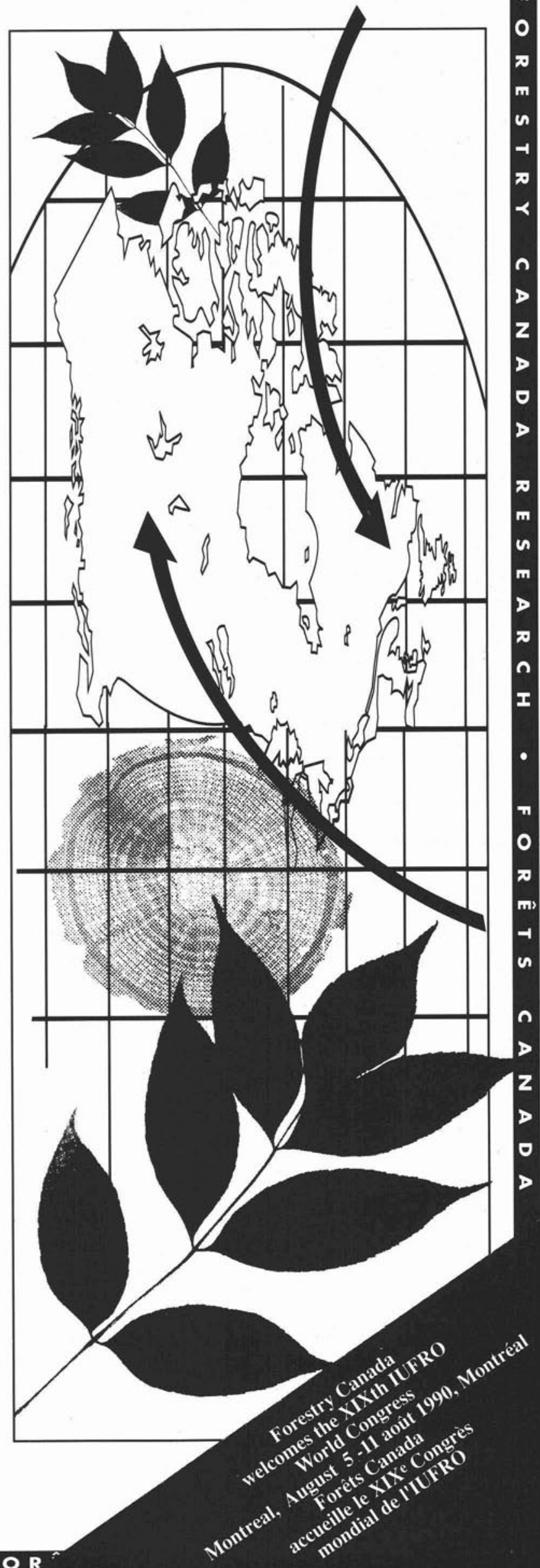

